\title{
PENYULUHAN GIZI DAN PEMBERDAYAAN EKONOMI PEREMPUAN KELURAHAN SINDANG BARANG BOGOR
}

\author{
Santi Susanti \\ Universitas Negeri Jakarta \\ ssusanti@unj.ac.id \\ Sri Zulaihati \\ Universitas Negeri Jakarta \\ sri_zulaihati@gmail.com
}

\begin{abstract}
Good toddlers growth is strongly supported by the fulfillment of nutritional needs. Parents in this case mothers who bond very closely with children are expected to provide and provide nutritious food to their children. Fulfilling children nutrition can not be separated from the economic level of society. Currently there are many families who are not able in economic terms and result in the fulfillment of childhood nutrition becomes a priority for the family. The way that mothers can provide nutritious food is by doing nutritional counseling, on the other hand also need an effort to increase family economic level with craft training so that empowerment of woman in family become optimal. This training is prepared by direct practice simulation method, and at final destination of this training is the mothers can provide nutritious food for balitanya and economic fulfillment through the training of making brooches that can supplement family income can be done in the spare time.
\end{abstract}

Key words: nutritional counseling, economic empowerment, women

\section{PENDAHULUAN}

\section{Analisis Situasi}

Kekurangan gizi pada masa balita dapat berpengaruh besar pada kualitas kehidupan manusia.Asupan gizi yang kurang pada dua tahun pertama kehidupan atau 1000 hari pertama kehidupan mempengaruhi kecerdasan anak. Pertumbuhan otak, 80 persen terjadi pada saat dalam kandungan sampai usia anak 2 tahun. Dampak lain dari kekurangan gizi adalah terjadi hambatan pada pertumbuhan fisik dan sistem kekebalan tubuhnya yang kurang sempurna.

Jumlah balita yang mengalami kekurangan gizi di wilayah Puskesmas Sindang Barang masih banyak. Bila dilihat dari angka statistik, persentasinya kecil jika dibandingkan dengan 
jumlah sasaran yang ada di wilayah ini. Namun demikian, meskipun persentasinya kecil, hal ini menyangkut masalah kemanusiaan dan masa depan bangsa dalam hal mencetak generasi yang unggul.

WHO dan Kementrian Kesehatan RI, mengklasifikasikan angka penentuan status gizi menjadi beberapa kategori, yaitu Berat Badan menurut Umur, Berat Badan menurut Tinggi Badan dan Tinggi Badan menurut Umur. Kekurangan gizi adalah balita yang mengalami kekurangan gizi baik akut maupun kronis.Adapun yang disebut dengan gizi buruk adalah kondisi gizi kurang hingga tingkat yang berat yang disebabkan oleh rendahnya konsumsi energi dan protein dari asupan makan balita sehari-hari dan terjadi dalam waktu yang cukup lama.

Terdapat banyak faktor yang dapat menyebabkan terjadinya kasus malnutrisi. WHO membatasinya menjadi dua faktor penyebab langsung terjadinya kasus gizi buruk yaitu kurangnya asupan gizi dari makanan dan penyakit infeksi. Kurangnya asupan gizi bisa disebabkan karena terbatasnya jumlah makanan yang dikonsumsi atau makanannya tidak memenuhi unsur gizi yang dibutuhkan. Sedangkan malnutrisi yang terjadi akibat penyakit disebabkan oleh rusaknya beberapa fungsi organ tubuh sehingga tidak bisa menyerap zat-zat makanan secara baik.

Faktor ketersediaan pangan yang bergizi dan terjangkau oleh masyarakat menjadi unsur yang penting dalam pemenuhan asupan gizi yang sesuai, selain perilaku dan budaya dalam pengolahan pangan dan pengasuhan anak. Pengelolaan lingkungan yang buruk dan perawatan kesehatan yang tidak memadai juga menjadi penyebab turunnya tingkat kesehatan yang memungkinkan timbulnya beragam penyakit.

Berdasarkan penanganan balidata BPS, jumlah penduduk yang masuk ke dalam kategori miskin di Kota Bogor pada Tahun 2009 mencapai $20 \%$. Sehingga kasus gizi buruk masih sering terjadi. Namun kemiskinan bukan satu-satunya akar masalah gizi buruk. Tingkat pengetahuan dan pendidikan yang rendah menjadi faktor penting terjadinya kasus gizi buruk. Tak sedikit kasus gizi buruk menimpa keluarga yang mapan secara ekonomi. Penyebabnya, keluarga tersebut tidak memiliki pengetahuan yang cukup tentang masalah gizi dan kesehatan.Ibarat rantai, banyak faktor yang saling terkait menjadi penyebab terjadinya lingkaran gizi buruk yang tiada habisnya.

Dampak dari permasalahan gizi buruk sangat kompleks.Gizi buruk dapat menyebabkan kematian anak, penyakit anak, gangguan pertumbuhan fisik, penurunan kemampuan belajar, penurunan kemampuan kognitif, anggaran pencegahan dan perawatan yang meningkat sampai pada penurunan produktivitas kerja yang akhirnya menimbulkan kerugian ekonomi. Ross dan Horton (1998) dalam Horton (1999), orang-orang yang mempunyai riwayat gizi buruk 
berat saat balita maka saat dewasa akan kehilangan produktivitasnya sebesar $2-9 \%$.

Jumlah balita gizi buruk di wilayah Puskesmas Sindang Barang sekitar 25 anak yang disebabkan kemiskinan dan pola asuh yang tidak tepat sebanyak 20 anak dan 5 anak yang disertai dengan penyakit. Sedangkan jumlah balita gizi kurang sekitar 75 anak yang sebagian besar disebabkan kemiskinan dan pola asuh yang tidak tepat. Bantuan penyuluhan melalui program pemberdayaan ekonomi dari kader posyandu dan partisipasi masyarakat diharapkan dapat membantu usaha perbaikan gizi dan penanggulangan gizi buruk. Pemberdayaan ekonomi yang tepat waktu dan tepat sasaran akan memberikan dampak pada peningkatan status gizi balita gizi buruk yang ditandai dengan peningkatan berat badan serta tinggi badan anak setiap bulannya.

\section{Tujuan Kegiatan}

Adapun tujuan-tujuan yang ingin dicapai dalam kegiatan ini adalah sebagai berikut.

a. Melaksanakan salah satu bentuk Tridarma Perguruan Tinggi, yaitu kegiatan pengabdian pada masyarakat oleh dosen PT.

b. Sebagai langkah nyata kontribusi dosen PT atas masalah pendidikan yang dihadapi dalam lingkup pendidikan ekonomi di Indonesia dan upaya mencerdaskan kehidupan bangsa.

c. Membantu menanggulangi masalah yang dihadapi di dalam dunia pendidikan, terutama dalam hal penerapanpemberdayaan ekonomi di wilayah Bogor.

\section{Rumusan Masalah}

Permasalahan di atas dapat digambarkan dalam bagan di bawah ini:

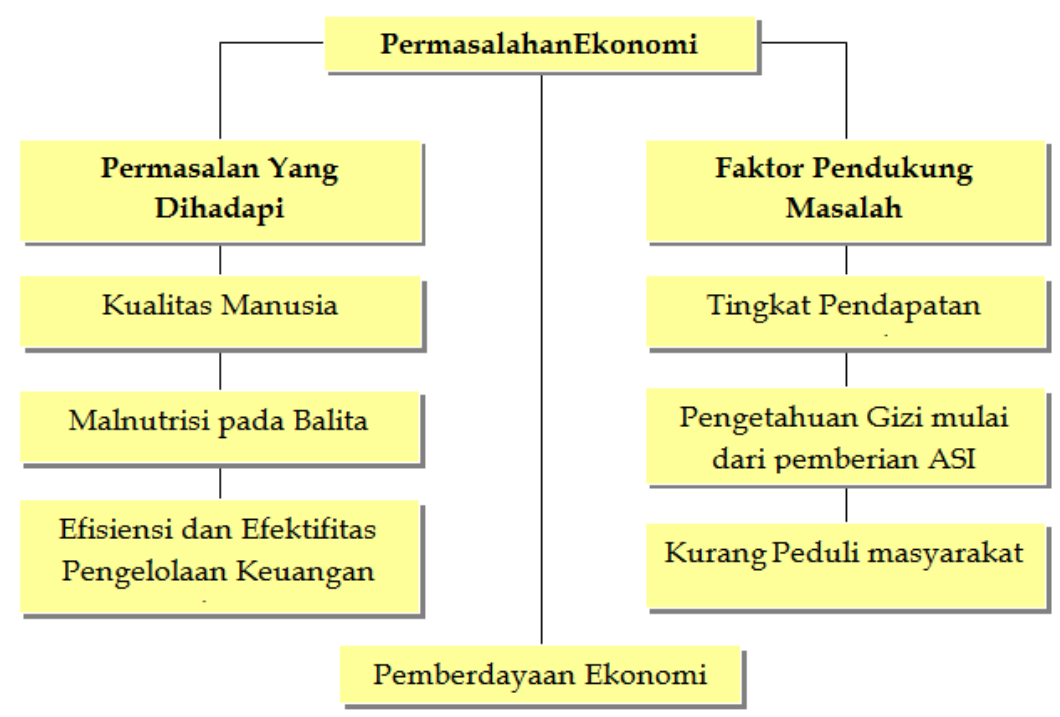

Gambar 1. Bagan Permasalahan Penelitian 


\section{Manfaat Kegiatan}

1. Bagi Kader Posyandu

Kegunaan kegiatan ini adalah sebagai upaya meningkatkan pengetahuan dan penerapannya dalam pemberdayaan ekonomi keluarga.

2. Bagi Masyarakat
a. Membangun kualitas manusia indonesia yang lebih sehat.
b. Menelaah masalah-masalah per- ekonomian yang dihadapi.
c. Memberikan inovasi baru dalam menghadapi masalah ekonomi masyarakat
d. Membangun tingkat keberdaya- an ekonomi masyarakat.

3. Bagi Civitas Akademika

Dosen sebagai pengabdi masyarakat dalam konteks Tridarma Perguruan Tinggi berperan sebagai fasilitator atas program tersebut. Manfaat yang akan diperoleh adalah tersalurkannya ilmu yang telah diterima dari pelatihan. Selain itu, ini adalah proses pembelajaran dengan realita sesungguhnya. Akan banyak hal yang akan ditemui selama pelaksanaan, menambah khasanah intelektual dalam membangun bangsa.

\section{KAJIAN TEORITIK \\ Pemberdayaan Ekonomi}

Pemberdayaan adalah terjemahan dari empowerment, sedang memberdayakanadalah terjemahan dari empower. Menurut merriam Webster dan Oxford English Dictionary, kata empower mengandung dua pengertian, yaitu: (1) to give power atauauthority to atau memberi kekuasaan, mengalihkan kekuatan atau mendelegasikan otoritas ke pihak lain; (2) to give ability to atau enable atau usaha untuk memberikemampuan atau keperdayaan.

Konsep pemberdayaan lahir sebagai antitesis terhadap model pembangunan dan model industrialisasi yang kurang memihak pada rakyat mayoritas. Konsep ini dibangundari kerangka logik sebagai berikut: (1) bahwa proses pemusatan kekuasan terbangundari pemusatan penguasaan faktor produksi; pemusatan kekuasaan faktor produksiakan melahirkan masyarakat pekerja dan masyarakat yang pengusaha pinggiran; (3) kekuasaan akan membangun bangunan atas atau sistem pengetahuan, sistem politik,sistem hukum, dan ideologi yang manipulatif untuk memperkuat dan legitimasi; dan (4) kooptasi sistem pengetahuan, sistem hukum, sistem politik, dan ideologi, secarasistematik akan menciptakan dua kelompok masyarakat, yaitu masyarakat berdaya dan masyarakat tunadaya. Akhirnya yang terjadi adalah dikotomi, yaitu masyarakat yang berkuasa dan manusia yang dikuasai. Untuk membebaskan situasi menguasai dan dikuasai, maka harus dilakukan pembebasan melalui proses pemberdayaan bagi yang dikuasai (empowerment of the powerless).

Pengalaman empirik dan pengalaman historis dari format sosial 
ekonomi yang dikotomis ini telah melahirkan berbagai pandangan mengenai pemberdayaan. Pandangan pertama, pemberdayaan adalah penghancuran kekuasaan atau power to nobody. Pandangan ini didasari oleh keyakinan, bahwa kekuasaan telah menterasingkandan menghancurkan manusia dari eksistensinya. Oleh sebab itu untuk mengembalikan eksistensi manusia dan menyelamatkan manusia dari keterasingan dan penindasan, maka kekuasaan harus dihapuskan. Pandangan kedua, pemberdayaan adalah pembagian kekuasaan kepada setiap orang (power to everybody). Pandangan ini didasarkan pada keyakinan, bahwa kekuasaan yang terpusat akan menimbulkan abusedan cenderung mengalienasi hak normatif manusia yang tidak berkuasa atau yang dikuasai. Oleh sebab itu, kekuasaan harus didistribusikan ke semua orang, agar semua orang dapat mengaktualisasikan diri. Pandangan ketiga, pemberdayaan adalah penguatan kepada yang lemah tanpa menghancurkan yang kuat. Pandangan ini adalahpandangan yang paling moderat dari dua pandangan lainnya. Pandangan ini adalahantitesis dari pandangan power to nobody dan pandangan power to everybody. Menurut pandangan ini, Power to nobody adalah kemustahilan dan power to everybody adalahchaos dan anarki. Oleh sebab itu menurut pandangan ketiga, yang paling realistis adalahpower to powerless.

Ketiga pandangan tersebut di atas, kalau dikaji secara seksama, ternyata berpengaruh cukup signifikan dalam konsep dan praksis pemberdayaan. Di lapangan,paling tidak ada 3 konsep pemberdayaan. Konsep pertama, pemberdayaan yang hanya berkutat di 'daun' dan 'ranting' atau pemberdayaan konformis. Karena struktur sosial, struktur ekonomi, dan struktur ekonomi sudah dianggap given, maka pemberdayaan adalah usaha bagaimana masyarakat tunadaya harus menyesuaikan dengan yang sudah given tersebut. Bentuk aksi dari konsep ini merubah sikap mental masyarakat tunadaya dan pemberian santunan, seperti misalnya pemberian bantuan modal, pembangunan prasarana pendidikan, dan sejenisnya. Konsep ini sering disebut sebagai magical paradigm. Konsep kedua, pemberdayaan yang hanya berkutat di 'batang' atau pemberdayaan reformis. Artinya, secara umum tatanan sosial, ekonomi, politik dan budaya, sudah tidak ada masalah. Masalah ada pada kebijakan operasional. Oleh sebab itu, pemberdayaan gaya ini adalah mengubah dari top down menjadi bottom up, sambil mengembangkan sumberdaya manusianya, menguatkan kelembagaannya, dan sejenisnya. Konsep ini sering disebut sebagai naive paradigm. Konsep ketiga, pemberdayaan yang hanya berkutat di 'akar' atau pemberdayaan struktural. Karena tidak berdayanya masyarakat disebabkan oleh struktur politik, ekonomi, dan sosial budaya, yang tidak memberi ruang bagi masyarakat lemah untuk berbagi kuasa dalam bidang ekonomi, politik, dan sosial 
budaya, maka stuktur itu yang harus ditinjau kembali. Artinya, pemberdayaan hanya dipahami sebagai penjungkirbalikan tatanan yang sudah ada. Semua tatanan dianggap salah dan oleh karenanya harus dihancurkan, seperti misalnya memfasilitasi rakyat untuk melawan pemerintah, memprovokasi masyarakat miskin untuk melawan orang kaya dan atau pengusaha, dan sejenisnya.

Singkat kata, konsep pemberdayaan masyarakat yang hanya berkutat pada akar adalah penggulingan the powerful. Konsep ketiga ini sering disebut sebagai critical paradigm. Oleh Pranarka dan Moelyarto (1996), karena kesalahpahaman mengenai pemberdayaan ini, maka menimbulkan pandangan yang salah, seperti bahwa pemberdayaan adalah proses penghancuran kekuasaan, proses penghancuran negara, dan proses penghancuran pemerintah.

Menurut Karl Marx, pemberdayaan masyarakat adalah proses perjuangan kaum powerless untuk memperolah surplus value sebagai hak normatifnya. Perjuangan memperoleh surplus value dilakukan melalui distribusi penguasaan faktor-faktor produksi. Dan perjuangan untuk mendistribusikan penguasaan faktorfaktor produksi harus dilakukan melalui perjuangan politik. Kalau menurut Marx, pemberdayaan adalah pemberdayaan masyarakat, maka menurut Fiedmann, pemberdayaan harus dimulai dari rumah tangga. Pemberdayaan rumah tangga adalah pemberdayaan yang mencakup aspek sosial, politik, dan psikologis. Yang dimaksud dengan pemberdayaan sosial adalah usaha bagaimana rumah tangga lemah memperoleh akses informasi, akses pengetahuan dan ketrampilan, akses untuk berpartisipasi dalam organisasi sosial, dan akses ke sumber-sumber keuangan. Yang dimaksud dengan pemberdayaan politik adalah usaha bagaimana rumah tangga yang lemah memiliki akses dalam proses pengambilan keputusan publik yang mempengaruhi masa depan mereka. Sedang pemberdayaan psikologis adalah usaha bagaimana membangun kepercayaan diri rumah tangga yang lemah. Selain Karl Marx dan Friedmann, masih banyak pandangan mengenai pengertian pemberdayaan, seperti Hulme dan Turner (1990), Robert Dahl(1963), Kassam (1989), sen dan Grown (1987), dan Paul (1987), yang pada prinsipnya adalah bahwa pemberdayaan adalah penguatan masyarakat untuk dapat berpartisipasi dalam proses pengambilan keputusan yang mempengaruhi masa depannya, penguatan masyarakat untuk dapat memperoleh faktorfaktor produksi, dan penguatan masyarakat untuk dapat menentukan pilihan masa depannya.

Dari berbagai pandangan mengenai konsep pemberdayaan, maka dapat disimpulkan, bahwa pemberdayaan ekonomi masyarakat adalah penguatan pemilikan faktorfaktor produksi, penguatan penguasaan distribusi dan pemasaran, penguatan masyarakat untuk 
mendapatkan gaji/upah yang memadai, dan penguatan masyarakat untuk memperoleh informasi, pengetahuan dan ketrampilan, yang harus dilakukan secara multi aspek, baik dari aspek masyarakatnya sendiri, mapun aspek kebijakannya. Karena persoalan atau isu strategis perekonomian masyarakat bersifat lokal spesifik dan problem spesifik, maka konsep dan operasional pemberdayaan ekonomi masyarakat tidak dapat diformulasikan secara generik. Usaha memformulasikan konsep, pendekatan, dan bentuk operasional pemberdayaan ekonomi masyarakat secara generik, memang penting, tetapi yang jauh lebih penting, adalah pemahaman bersama secara jernih terhadap karakteristik permasalahan ketidakberdayaan masyarakat di bidang ekonomi. Sebab dengan pemahaman yang jernih mengenai ini, akan lebih produktif dalam memformulasikan konsep, pendekatan, dan bentuk operasional pemberdayaan ekonomi masyarakat yangsesuai dengan karakteristik permasalahan lokal. Berikut adalah salah satu contoh problem spesifik yang dihadapi masyarakat tunadaya dalam bidang akses faktor produksi modal.

\section{Permasalahan Kekurangan Gizi Balita}

Di negara berkembang, lebih dari sepuluh juta balita meninggal dunia pertahun, 2/3 dari kematian tersebut terkait dengan masalah gizi yang sebenarnya dapat dihindar-kan. Penelitian di 42 negara berkembang menunjukkan bahwa pemberian ASI secara eksklusif selama enam bulan merupakan intervensi kesehatan masyarakat yang mempunyai dampak positif terbesar untuk menurunkan angka kematian balita, yaitu sekitar 13\%. Pemberian makanan pendamping ASI yang benar dapat menurunkan angka kematian balita sebesar $6 \%$. Berdasarkan hasil penelitian tersebut, perilaku memberikan ASI secara eksklusif pada bayi sejak lahir hingga usia 6 bulan dapat menurunkan angka kematian 30.000 bayi di Indonesia tiap tahunnya (Sentra Laktasi Indonesia, 2007).

Berdasarkan hasil Survey Demografi Kesehatan Indonesia (SDKI) 2003, hanya 3,7\% bayi yang memperoleh ASI pada hari pertama, sedangkan pemberian ASI pada usia 2 bulan pertama $64 \%$, yang kemudian menurun pada periode berikutnya umur 3 bulan $45,5 \%$ pada usia $4-5$ bulan $13,9 \%$ dan umur $6-7$ bulan $7,8 \%$. Sementara itu ada peningkatan penggunaan pengganti air susu ibu (PASI) yang biasa disebut formula atau susu formula tiga kali lipat dalam kurun waktu 1997 dari 10,8\% menjadi $32,4 \%$ pada tahun 2002, hal ini mungkin diakibatkan kurangnya pemahaman, dukungan keluarga dan lingkungan akan pemberian ASI secara eksklusif (Tjipta, 2009).

Permasalahan gizi pada anak usia balita di Indonesia memang sudah mulai menurun, namun tatap saja masih ada segelintir orang yang mengalami masalah nasib kurang beruntung ini. Banyak faktor yang 
menyebabkan masalah kurang gizi ini, sehingga masih menerpa anak - anak yang sedang tumbuh. Penyebab utamanya tentu pola asuh dan pola asupan nutrisi yang kurang baik dari orang tuanya. Masalah gizi ini juga erat hubungannya dengan permasalahan ekonomi dalam suatu rumah tangga.

Banyak orang tua yang masih
awam dan kurang memahami penyebab terjadinya gizi buruk pada buah hatinya, terutama orang - orang yang berada di pesisir atau di pelosok. Masalah kurang gizi ini sebenarnya dapat dipengaruhi oleh beberapa hal berikut:

- Keadaan ekonomi yang kurang beruntung

Keuangan keluarga yang berada dibawah garis kemiskinan tentunya akan mempengaruhi kemampuan orang tua untuk menyediakan asupan nutrisi yang cukup. Dengan keadaan yang pas-pasan tentunya orang tua akan mengabaikan makanan-makanan atau nutrisi penunjang yang sebenarnya sangat dibutuhkan oleh anak yang sedang tumbuh berkembang.

- Kurangnya pengetahuan orang tua Orang tua tentunya memiliki peran yang sangat besar pada masalah ini. Orang tua yang tidak memiliki pengetahuan yang cukup tentang pentingnya asupan gizi pada anak, pasti tidak akan terlalu memperhatikan masalah ini.

- Gaya hidup yang tidak sehat Kehidupan yang kumuh dan jauh dari kata bersih akan turut menjadi penyebab masalah ini. keadaan yang tidak bersih akan berdampak pada kondisi makanan yang kurang sehat dan higenis sehingga dapat menyebabkan timbulnya penyakit pada anak.

- Anak sering terserang sakit

Kekebalan atau imunitas tubuh yang masih rendah membuat anak rentan terserang berbagai jenis penyakit. Seorang anak yang sering mengidap sakit baik ringan ataupun berat biasanya akan mengalami masalah pada tingkat gizinya. Terlebih anak yang kurang sehat biasanya akan kehilangan nafsu makan, sehingga asupan nutrisinya tidak terjaga dengan baik.

UNICEF dalam Soekirman (2002) juga telah memperkenalkan dan sudah digunakan secara internasional mengenai berbagai faktor penyebab timbulnya gizi kurang pada balita, yaitu:

1. Penyebab langsung

Yaitu makanan tidak seimbang untuk anak dan penyakit infeksi yang mungkin diderita anak.Anak yang mendapat makanan yang cukup tetapi diserang diare atau infeksi, nafsu makan menurun, akhirnya dapat menderita gizi kurang.Sebaliknya, anak yang makan tidak cukup baik, daya tahan tubuh melemah, mudah diserang infeksi.

Kebersihan lingkungan, tersedianya air bersih, dan berperilaku hidup bersih dan sehat akan menentukan tingginya kejadian penyakit infeksi.

2. Penyebab tidak langsung 
Pertama, ketahanan pangan dalam keluarga adalah kemampuan keluarga untuk memenuhi kebutuhan makan untuk seluruh anggota keluarga baik dalam jumlah maupun dalam komposisi zat gizinya. Kedua, pola pengasuhan anak, berupa perilaku ibu atau pengasuh lain dalam hal memberikan makan, merawat, kebersihan memberi kasih sayang dan sebagainya.

Kesemuanya berhubungan dengan kesehatan ibu (fisik dan mental), status gizi, pendidikan, pengetahuan, pekerjaan, adat kebiasaan dan sebagainya dari si ibu dan pengasuh lainnya. Ketiga, faktor pelayanan kesehatan yang baik, seperti; imunisasi, penimbangan anak, pendidikan dan kesehatan gizi, serta pelayanan posyandu, puskesmas, praktik bidan, dokter dan rumah sakit.

\section{Penanggulangan Masalah Gizi Buruk pada Balita}

Dalam hal penanggulangan masalah gizi buruk pada balita, tidak terlepas dari peran ibu dan lingkungan sekitar.Masalah gizi buruk ini juga terkait dengan tingkat pendapatan ekonomi dari masyarakat yang masih rendah. Karena itu diperlukan pemberdayaan ekonomi sekaligus penambahan pengetahuan gizi bagi kader posyandu yang menjadi kader aktif yang akan menjadi penyuluh di tingkat RT/RW setempat.

\section{METODOLOGI}

\section{Kerangka Pemecahan Masalah}

Kerangka atau tahapan dalam Pelatihan Pemberdayaan Ekonomi bagi Kader Posyandu di Kel. Sindang Barang Bogor.

\section{Analisis Kebutuhan}

Berdasarkan diskusi yang dilakukan oleh tim pengabdian masyarakat pada kegiatan Pelatihan Pemberdayaan Ekonomi bagi Kader Posyandu di Kel. Sindang Barang Bogor, terdapat ketimpangan sebagai berikut:

1. Kurang tepatnya pembinaan para kader posyandu bagi peningkatan gizi Balita yang dimulai dari pemberian ASI.

2. Kurangnya sumber atau materi pengetahuan dari kader posyandu yang tidak mempunyai latar belakang pendidikan tinggi tentang gizi dan pemberdayaan ekonomi.

3. Masih rendahnya tingkat pendapatan ekonomi masyarakat, sehingga banyak yang menyepelekan tentang gizi anak balita.

\section{Rancangan Instruksional}

Dalam menentukan rancangan instruksional ini perlu dipertimbangkan aspek-aspek berikut :

1. Isi materi program pelatihan yang relevan dengan kebutuhan mereka. Tim ini telah memetakan kebutuhan materi keseluruhan bagi Kader Posyandu di Kel. Sindang Barang Bogor.

2. Latar belakang pendidikan Kader Posyandu di Kel. Sindang Barang Bogor. 
3. Modul Pedoman pemberian Gizi Balita bagi Kader Posyandu di Kel. Sindang Barang Bogor.

\section{Tahap Pengembangan}

Dalam rangka pengembangan pemberdayaan ekonomi, tim pengabdian masyarakat berupaya mengembangkan pelatihan ini baik dalam hal materi pelatihan pemberdayaan ekonomi, modul dan tanya jawab materi yang di sampaikan terkait dengan peningkatan gizi balita.

\section{Realisasi Pemecahan Masalah Pelaksanaan}

Pelaksanaan program pelatihan ini dilaksanakanselama 2 hari Sabtu, 10 dan17 September 2016 di rumah salah satu kader Posyandu di kelurahan Sindang Barang Bogor. Waktu yang dimulai pada jam 08.00 - 12.00 WIB.

\section{Evaluasi}

Tim pengabdian masyarakat akan menyusun evaluasi terkait dengan pemahaman peserta terhadap materi pelatihan, pelaksanaan pelatihan secara keseluruhan untuk menampung kemungkinan dibutuhkannya pelatihan dengan materi lain dan tertibnya pelaksanaan program pelatihan ini.

\section{Khalayak Sasaran}

Target sasaran kegiatan Pelatihan Pemberdayaan Ekonomi bagi Kader Posyandu di Kel. Sindang Barang Bogor. Peserta yang akan hadir sebanyak +20 orang yaitu seluruh kader Posyandu di wilayah Kel. Sindang Barang, Bogor.

\section{Metode Yang Digunakan}

Pelaksanaan penerapan model pelatihan efektif pemberdayaan ekonomi ini dilaksanakan melalui metode workshop yang bersifat partisipatoriemansipatoris, yaitu suatu upaya yang dilakukan melalui proses partisipasi aktif dalampenerapan pemberdayaan ekonomi dan penyuluhan gizi balita.

\section{Pendekatan Untuk Pelaksanaan Tahap I (Pemetaan) \\ Pemetaan dimaksudkan untuk} mengidentifikasi peserta yang akan mengikuti workshop kegiatan Pelatihan Pemberdayaan Ekonomi bagi Kader Posyandu di Kel. Sindang Barang Bogor.

\section{Pendekatan Untuk Pelaksanaan Tahap II}

Sosialisasi dilakukan dengan cara mengunjungi Kelurahan tempat Pelatihan yang akan berlangsung. Pelatihan dilakukan melalui metode pendekatan practical learning yang emansipatif-partisipatori oleh para Kader Posyandu. Pemberian pemahaman juga diberikan melalui simulasi peningkatan produksi ASI dan pembuatan bros. Metode pelatihan yang digunakan pada program pelatihan ini diharapkan dapat memberikan kemudahan kepada peserta pelatihan. Dalam pelatihan ini, metode yang digunakan adalah Metode Praktekdan Tanya Jawab. Pada Metode Praktek, setiap instruktur 
mencontohkan dan kemudian dilanjutkan dengan peserta lagsung mempraktekan. Instruktur menyiapkan perlengkapan yang dibutuhkan dalam pelatihan pembuatan bros pita.Alat bantu pelatihan seperti LCD proyektor juga digunakan agar peserta lebih mudah memahami materi pelatihan sementara instruktur lainnya juga mendampingi para peserta untuk memantau pertanyaan-pertanyaan selama sesi praktek dan tanya jawab.

\section{Materi Pelatihan \& Instruktur}

Materi pelatihan yang akan disampaikan dan instruktur pada program pelatihan ini adalah merupakan Tim Instruktur Fakultas Ekonomi UNJ dan bekerja sama dengan Tim Penyuluh Gizi dari Puskesmas Kel. Sindang Barang, Bogor.

\section{HASIL DAN PEMBAHASAN Pelaksanaan}

Pemahaman pemberian gizi yang selama ini diabaikan untuk bayi dan balita masih kurang dipahami ataupun dipraktekan. Dimulai pada masa menyusui, masih banyak yang belum sadar akan pentingnya pemberian ASI pada usia sampai 2 tahun, hal ini menyebabkan gizi Balita juga berkurang, ditambah lagi karena kehidupan ekonomi yang kurang, Balita juga tidak mendapatkan pemberian makanan dengan asupan gizi yang sehat.

Pemberdayaan Ekonomi masyarakat dirasa perlu terutama untuk para ibu-ibu yang masih muda dan produktif. Salah satu cara pemberdayaan ekonomi adalah melalui pemberian keterampilan yang dapat meningkatkan penghasilan para ibuibu muda tersebut.

Peserta yang hadir pada kegiatan ini sekitar 20 orang yang merupakan ibu-ibu muda kader Posyandu di wilayah Kel. Sindang Barang pada 10 dan 17 September 2016. Kegiatan ini adalah pengabdian kepada masyarakat yang dilaksanakan oleh dosen-dosen sebagai sebuah kewajiban Tridharma Perguruan Tinggi.

\section{Materi dan Instruktur Pelatihan}

Materi pelatihan yang akan disampaikan dan Instruktur pada program pelatihan ini dijelaskan pada tabel di bawah ini.

Tabel Materi Pelatihan dan Instruktur

\begin{tabular}{|c|lr|l|c|}
\hline No. & \multicolumn{2}{|c|}{ Materi Pelatihan } & \multicolumn{1}{c|}{ Instruktur } & Jumlah Jam \\
\hline 1 & $\begin{array}{l}\text { Pemberdayaan Ekonomi } \\
\text { melalui } \\
\text { Keterampilan }\end{array}$ & $\begin{array}{l}\text { Santi Susanti dan } \\
\text { tim }\end{array}$ & Jam \\
\hline 2 & $\begin{array}{l}\text { Peningkatan Pemberian ASI } \\
\text { bagi bayi }\end{array}$ & $\begin{array}{l}\text { Tim Puskesmas } \\
\text { Sindang Barang }\end{array}$ & 4 Jam \\
\hline
\end{tabular}


Materi yang diberikan meliputi materi seputar asi eksklusif: manfaat ASI untuk ibu dan bayi, cara menyusui yang tepat, tips memperbanyak jumlah ASI. Masalah yang dialami adalah sulit untuk membangun kesadaran dan kemauan ibu hamil untuk berjuang memberikan asi eksklusif, yang juga dapat disebabkan oleh kurangnya dukungan dari suami atau keluarga terdekat. Perlunya diadakan lagi kelas ASI secara rutin di setiap kesempatan untuk membangun kesadaran dan memotivasi ibu menyusu asi eksklusif pada bayinya sampai berusia 6 bulan. Penyuluhan yang berkesinambungan dengan harapan terbentuknya komunitas pemberi asi eksklusif di wilayah masing-masing.

\section{Refleksi Atas Pelaksanaan}

Pembangunan kesehatan bertujuan meningkatkan kesehatan, kemampuan dan kemauan hidup sehat bagi setiap penduduk agar dapat mewujudkan derajat kesehatan yang optimal. Dengan kata lain, masyarakat diharapkan mampu berpartisipasi aktif dalam memelihara dan meningkatkan derajat kesehatannya sendiri.

Untuk mencapai derajat kesehatan masyarakat yang optimal banyak faktor yang mempengaruhinya dan faktor yang paling besar pengaruhnya adalah lingkungan dan perilaku. Kondisi lingkungan yang jelek dan perilaku yang tidak sehat dapat menurunkan kualitas SDM.

Pemberian air susu ibu (ASI) sangat penting bagi tumbuh kembang yang optimal baik fisik maupun mental dan kecerdasan bayi. Oleh karena itu, pemberian ASI perlu mendapat perhatian para ibu dan tenaga kesehatan agar proses menyusui dapat terlaksana dengan benar (Afifah, 2007). Selain itu, pemberian ASI dapat menurunkan risiko kematian bayi (Nurmiati, 2008).

Pemberian ASI eksklusif adalah langkah awal bagi bayi untuk tumbuh sehat dan terciptanya sumber daya manusia yang tangguh, karena bayi tidak saja akan lebih sehat dan cerdas, tetapi juga akan memiliki emotional quotion (EQ) dan social quotion (SQ) yang lebih baik (Sentra Laktasi Indonesia, 2007). Berdasarkan laporan 500 penelitian, The Agency for Healthcare Research and Quality menyatakan bahwa pemberian ASI berhubungan dengan pengurangan resiko terhadap otitis media, diare, infeksi saluran pernafasan bawah dan enterokolitis nekrotikans (Massachusetts Department of Public Health Bureau of Family Health and Nutrition, 2008).

Namun pada kenyataannya, pengetahuan masyarakat tentang ASI eksklusif masih sangat kurang, misalkan ibu sering memberikan makanan padat kepada bayi yang baru berumur beberapa hari atau beberapa minggu seperti memberikan nasi yang dihaluskan atau pisang. Kadang-kadang ibu mengatakan air susunya tidak keluar atau keluarnya hanya sedikit pada hari-hari pertama kelahiran bayinya, kemudian membuang ASI-nya tersebut dan menggantikannya dengan madu, gula, mentega atau makanan lainnya. 
Pemberdayaan Ekonomi para ibu muda juga diperlukan dalam rangka meningkatkan keterampilan dalam memproduksi barang dan jasa yang bermanfaat untuk meningkatkan perekonomian.Walau awalnya mereka kesulitan dengan pembuatan bros, tapi setelah terlatih mereka bersemangat dalam membuat bros, tetapi masih diperlukan bimbingan dalam penyempurnaan dan pemasaran barang di kemudian hari.

\section{KESIMPULAN DAN SARAN Simpulan}

Dengan adanya kegiatan ini diharapkan dapat memberikan manfaat dan menambah khasanah dan sumber pengetahuan bagi para peserta sosialisasi serta para pembaca laporan ini. Peningkatan pengetahuan gizi dan peningkatan keterampilan bagi para ibu muda dapat bermanfaat untuk memberdayakan ekonomi rumah tangga mereka.

Hasil yang dicapai atas pelatihan peningkatan gizi balita melalui peningkatan penggunaan ASI dan juga pembekalan keterampilan pembuatan bros pita ini harus terus ditidaklanjuti guna peningkatan perberdayaan ekonomi rumah tangga di masa yang akan datang.

\section{Saran}

Di masa yang akan datang diharapkan pelatihan tidak hanya mengenai keterampilan dan peningkatan gizi balita saja, tapi peningkatan soft skill untuk mengembangkan usaha ibu rumah tangga melalui manajemen usaha kecil dan menengah, sehingga mereka bisa bersaing dalam pasar global.

\section{DAFTAR PUSTAKA}

Projono, O.S dan Pranarka, A.M.W (1996). Pemberdayan: Konsep, Kebijakan dan implementasi.CSIS; Jakarta h.: 269: 1-4.

http://tokogeo.com/267/faktorpenyebab-kekurangan-gizipada-balita-di-indonesia 